UDC 633.112:57.085.2

\title{
THE INFLUENCE OF SUGAR SOURCE IN INDUCTION CULTURAL MEDIA ON THE EFFECTIVENESS OF CALLUS FORMATION AND PLANT REGENERATION IN DURUM CULTURE OF WHEAT ANTHER IN VITRO
}

\author{
H. O. Dobrova, I. S. Zambriborsh, O. L. Shestopal \\ The Plant Breeding and Genetics Institute - National Center of Seed \& Cultivar Investigation \\ 3, Ovidiopolska Road, Odessa 65036, Ukraine \\ e-mail: dobrovaann@gmail.com
}

Double haploids are important for durum wheat breeding. Anther culture method for obtaining double haploid is one of the most popular. Effectiveness of this method depends on different factors such as cultural condition and plant genotype. It is important to investigate the impact of cultural condition on the level of callus induction and plant regeneration. Sugar source in cultural media affects a process of androgenesis in vitro. Ability of four winter and four spring durum wheat hybrids F2 to androgenesis in vitro was studied. Two induction media with different sugar source were compared. C17M media contained maltose in $90 \mathrm{~g} / \mathrm{l}$ concentration. C17n media contained sucrose in $60 \mathrm{~g} / \mathrm{l}$ concentration and glucose in $17.5 \mathrm{~g} / \mathrm{l}$ concentration. It was estimated that the level of callus induction and albino plant regeneration were higher on the media with maltose for all investigated genotypes. The level of green plants regeneration was low. Green plants were obtained only for three genotypes. Three green double haploids of T12 genotype obtained from new formations on C17M media, were successfully cultivated in soil and produced seeds. Analysis of variances (ANOVA) was used for statistical analysis. The percentage of total variance accounted for each factor was calculated. It was established that plant genotype had the most significant influence on callus induction. Interaction between factor of genotype and induction cultural media had the biggest percentage of total variance accounted for albino and green plants regeneration.

Keywords: wheat durum, double haploids, anther culture, maltose.

\section{INTRODUCTION}

Double haploid is an efficient biotechnological method in wheat breeding which can significantly accelerate the process of production of new varieties. In vitro anther culture is one of the most important methods of haploid plants obtaining. Presently we have only limited knowledge about androgenesis in wheat durum. It was reported that this cereal is recalcitrant regarding anther culture because of its low ability to regenerate green plants [1, 9].

ISSN 1996-4536 (print) • ISSN 2311-0783 (on-line) • Біологічні Студії / Studia Biologica • 2015 • Том 9/№3-4 • С. 99-106 
Several factors which influenced anther culture have been studied, including genotype of the explants [1] and culture conditions [17].

Most of the induction cultural media contain high sugar concentration (6-10\%). Nutritional requirements for androgenesis and formed embryos growth are different [19]. For many plant species maltose has been known as a better carbohydrate source in comparison to sucrose for androgenesis. The use of maltose instead of sucrose as a carbohydrate source in culture medium led to a substantial stimulation of microspore embryogenesis, plant regeneration, and green plantlet formation [6, 10, 11$]$.

The effects of maltose have been documented in several tissue culture systems, but the reason for their superiority to sucrose is not known. It was demonstrated that maltose improves the osmotic stability of culture medium compared to sucrose [4]. It has also been reported that maltose stimulates embryogenesis at low concentrations [14]. It was estimated that utilization of maltose as sugar source lasted for a longer period due to a slower rate of hydrolysis compared to sucrose [8]. Besides, it is assumed that fructose, which is a side product of sucrose hydrolysis, inhibits androgenesis in vitro [5]. Maltose may be more effective source of sugar due to the fact that the rate of hydrolysis is close to the rate of glucose uptake during embryos germination [12].

Effect of sugar agents on durum culture of wheat anther were tested in several investigations $[9,16]$. The anthers were cultured on media with different carbon sources: sucrose and maltose. Supplements in culture medium significantly affected calli induction and plant regeneration. The number of calli and plants on the medium with maltose were significantly higher than the medium with sucrose. The green plant regeneration was effected by the initiation medium as well as genotypes. Maximum response was found on the medium with maltose.

The aim of this investigation was to determine the impact of sugar source in the induction cultural media on the effectiveness of calli production and plant regeneration in durum culture of wheat anther in vitro.

Two induction cultural media with different sugar source were compared. The influence of plant genotype and cultural media on callus induction and plant regeneration in vitro was estimated.

\section{MATERIALS AND METHODS}

Four spring and four winter wheat durum hybrids F2 were used as anther donors (Table 1). For spike pretreatment low positive temperatures $\left(+3-+5{ }^{\circ} \mathrm{C}\right)$ in water for 7 days were used [15]. Spikes were sterilized with calcium hypochlorite solution using the method [3]. The experiment was set up with two induction media: C17n nd C17M. Induction media were identical except the source of sugar. C17n media contained $6 \%$ of sucrose and $1.75 \%$ of glucose and C17M media contained $9 \%$ of maltose. Both media contained $2 \mathrm{mg} / \mathrm{l} 2,4-\mathrm{D}$ and $0.5 \mathrm{mg} / \mathrm{l}$ kinetin [18]. Anthers were incubated in dark at $+24{ }^{\circ} \mathrm{C}$ [2].

After 15-25 days of cultivation new formations were transferred to regeneration media MS cultural media with BAP (1 mg/l) and IAA (1 mg/l), proline $(200 \mathrm{mg} / \mathrm{l})$ and glutamine $(200 \mathrm{mg} / \mathrm{l})$. New formations were incubated in dark. Callus with regenerative zones or embryos were transferred to S MS media without growth regulators [7] and in a growth room at $25^{\circ} \mathrm{C}$ with $16 \mathrm{~h}$ light $/ 8 \mathrm{~h}$ dark photoperiod [2].

ISSN 1996-4536 (print) • ISSN 2311-0783 (on-line) • Біологічні Студії / Studia Biologica • 2015 • Том 9/№3-4 • С. 99-106 
Table 1. The studied hybrids of winter and spring wheat durum

Таблиця 1. Озимі та ярі гібриди пшениці твердої, залучені до дослідження

\begin{tabular}{|c|c|c|}
\hline Type & No & Genotype \\
\hline \multirow{4}{*}{ 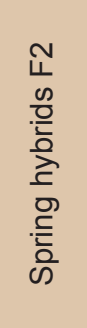 } & $\mathrm{T} 1$ & (Saratovsky Zolotiy $\times$ Gidara 2) $\times$ Gardemaryn \\
\hline & T8 & $\begin{array}{l}\text { Topdy } 1 \text { /FOCHA1/Altar84 } \times /(\text { Yav7 } 79 \times \text { Aliy Parus }) \times\{\text { Koral Odessky } \times \\
{[(\text { LR- } 1 \times 504 / 67) \times \text { Kharkivska } 1] \times[(\text { Tigris } \times \text { Aisberg Odessky }) \times(\text { Aisberg }} \\
\text { Odessky } \times \text { Novynka } 4)]\} /\end{array}$ \\
\hline & T12 & $\begin{array}{l}\text { Haurani } \times /(\text { Yav79 } \times \text { Aliy Parus }) \times\{\text { Koral Odessky } \times[(\text { LR }-1 \times 504 / 67) \times \\
\text { Xap.1 }] \times[(\text { Tigris } \times \text { Aisberg Odessky }) \times(\text { Aisberg Odessky } \times \text { Novynka } 4)]\} /\end{array}$ \\
\hline & T15 & Topdy 18/FOCHA1/Altar84 × Bosfor \\
\hline \multirow{4}{*}{ 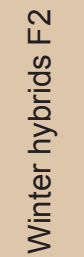 } & T42 & DF-900-83/WPB-881 × Novynka4 \\
\hline & T43 & DF-900-83/WBK-881 × Linkor \\
\hline & T44 & DF-900-83/WBK-881 × Zolote Runo \\
\hline & T45 & DF-900-83/WBK-881 × Yantar Odessky \\
\hline
\end{tabular}

The level of induction and regeneration was calculated as a callus and albino and green regenerated plants percentage upon total number of callus and confidence interval for each experimental variant. Analysis of variance (ANOVA) was used for statistical analysis [13].

\section{RESULTS AND DISCUSSION}

Level of induction of all tested genotypes was higher on C17M media (Fig.1). Albino plant regeneration of spring hybrids was observed only for callus on C17M media. Level of winter hybrids albino plant regeneration was higher for callus on C17M media (Fig. 2).

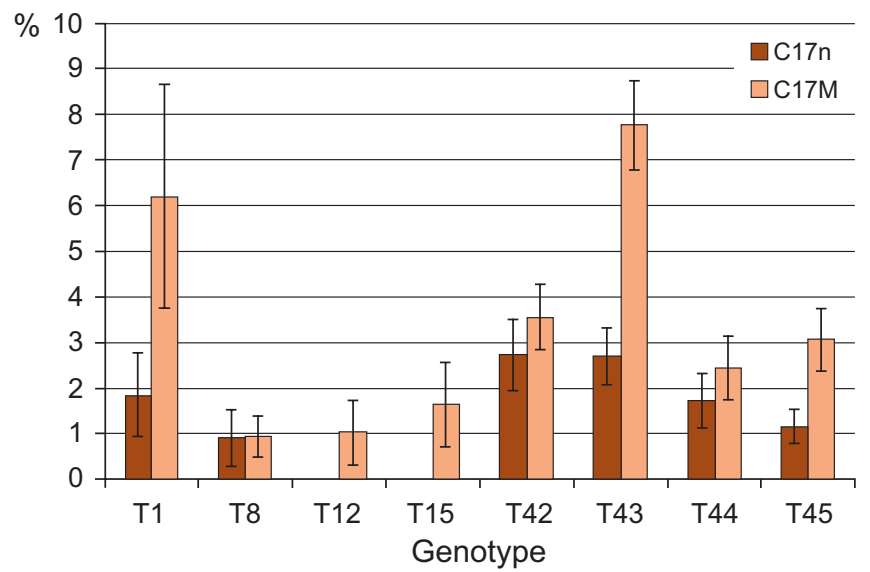

Fig. 1. Frequency of callus induction of different wheat durum genotypes on $\mathrm{C} 17 \mathrm{n}$ and $\mathrm{C} 17 \mathrm{M}$ induction media

Рис. 1. Частота індукції новоутворень різних генотипів пшениці твердої на поживних середовищах С17н і C17M 
Level of green plant regeneration was low. On C17M media it was $0.51 \pm 0.51 \%$ for $\mathrm{T} 12$ and $0.26 \pm 0.19 \%$ for T43. On C17n media it was $0.77 \pm 0.54 \%$ for T32. Three green plants of T12 were successfully adopted in soil and cultivated in growth chamber. Plants were double haploids and produced seeds. Green plants of T32 and T43 were defective and could not be adopted in soil. In general, the media with maltose was more effective for callus induction and plant regeneration for most of studied plant genotypes.

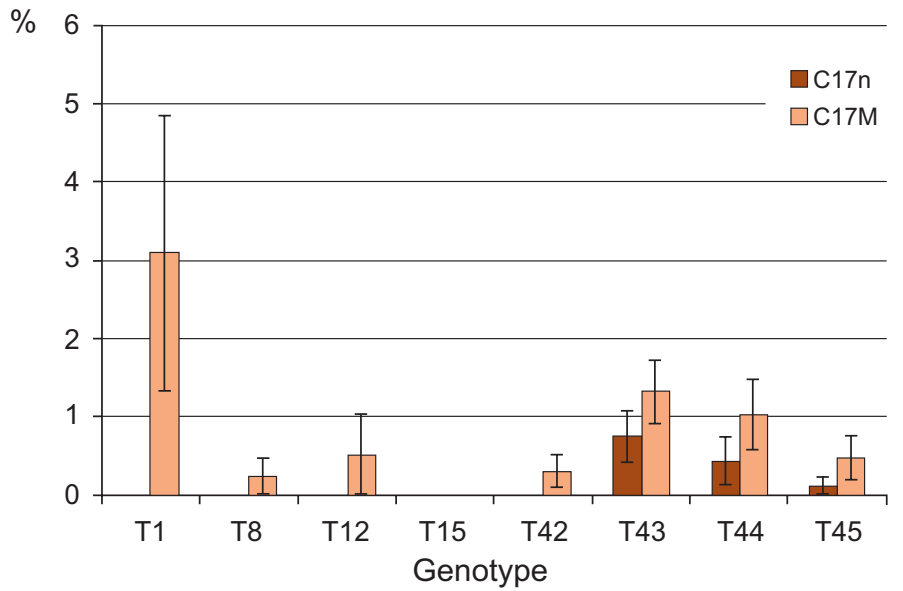

Fig. 2. Frequency of albino plant regeneration of different wheat durum genotypes from new formations obtained on C17n and C17M induction media

Рис. 2. Частота регенерації альбіно рослин різних генотипів пшениці твердої з новоутворень, отриманих на індукційних середовищах С17н і С17M

Table 2. Two factor analysis of variance of callus induction and albino and green plants regeneration level

Таблиця 2. Двофакторний дисперсійний аналіз даних рівня індукції новоутворень і регенерації альбіно та зелених рослин

\begin{tabular}{|c|c|c|c|}
\hline Process & Variances & $\mathrm{F}$ & $\mathrm{h}, \%$ \\
\hline \multirow{3}{*}{ Induction } & Main effect of factor A: genotype & $23.50^{* *}$ & 55.89 \\
\hline & Main effect of factor B: induction cultural media & $49.80^{* *}$ & 16.92 \\
\hline & Interaction $\mathrm{A}$ and $\mathrm{B}$ & $6.86^{* *}$ & 16.32 \\
\hline \multirow{3}{*}{ Albino plant regeneration } & Main effect of factor A: genotype & $7.27^{\star *}$ & 34.54 \\
\hline & Main effect of factor B: induction cultural media & $11.98^{* *}$ & 8.13 \\
\hline & Interaction $\mathrm{A}$ and $\mathrm{B}$ & $7.50^{* *}$ & 35.62 \\
\hline \multirow{3}{*}{ Green plant regeneration } & Main effect of factor A: genotype & $6.99^{* *}$ & 31.54 \\
\hline & Main effect of factor B: induction cultural media & $13.29 * *$ & 8.56 \\
\hline & Interaction $\mathrm{A}$ and $\mathrm{B}$ & $8.71^{* *}$ & 39.28 \\
\hline
\end{tabular}

Comments: ** - significant at $\mathrm{p} \leq 0.01 ; \mathrm{h}$ - the percent of total variance accounted for each factor

Примітки: ** - достовірно при $\mathrm{p} \leq 0,01 ; \mathrm{h}$ - відсоток від загальної дисперсії, розрахований для кожного фактора

ISSN 1996-4536 (print) • ISSN 2311-0783 (on-line) • Біологічні Студії / Studia Biologica • 2015 • Том 9/№3-4 • C. 99-106 
Two-factor analysis of variance with factors of plant genotype and induction cultural media was used to check the impact of sugar sources and plant genotype on the level of callus induction and albino and green plant regeneration (Table 2). Two factors and its interaction affected significantly both the level of callus induction and plant regeneration. The highest percent of total variance for callus induction was $55.89 \%$ accounted for genotype factor. The highest percent of total variance for albino and green plant regeneration was $35.62 \%$ and $39.28 \%$, correspondingly. It was accounted for interaction between two factors. Percent of total variance for factor of induction cultural media was $16.92 \%$ for callus induction, $8.13 \%$ for albino plant regeneration and $8.56 \%$ for green plant regeneration. Since induction media were different only with sugar source, it can be concluded that maltose had a significant influence on in vitro callus induction and plant regeneration.

\section{CONCLUSIONS}

1. The influence of sugar source and genotype on the level of callus induction and plant regeneration in wheat anther durum culture in vitro was estimated. It was found that sugar source had a significant influence on wheat anther durum culture effectiveness.

2. Maltose is shown to be more effective sugar source comparing with sucrose. It was established that the level of callus induction and plant regeneration was higher on the media with maltose comparing with media with sucrose and glucose.

3. Three fertile double haploid plants of T12 genotype were obtained.

1. Carreda S., Clement C. Androgenesis and albinism in Poaceae: influence of genotype and carbohydrates. Berlin: Springer, 1999: 263 p.

2. Grauda D., Mikelsone A., Lisina N. et al. Anther culture effectiveness in producing doubled haploids of cereals. Proceedings of The Latvian Academy of Sciences, 2014; 68 (3/4): 142-147.

3. Ignatova S.O., Zhosonar M.V., Lobanova K.I. et al. Obtaining of spring wheat doublehaploid by anther culture. Methodical recommendations. Odessa: South Plant Biotechnological Center UAAN, 2008: 1-12. (In Ukrainian).

4. Kuhlmann U., Foroughi-Wehr B. Production of double haploid line in frequencies sufficient of barley breeding program. Plant Cell Reports, 1989; 8(2): 78-81.

5. Last D.I., Brettell R.I.S. Embryo yield in wheat anther culture is influenced by the choice of sugar in the culture medium. Plant Cell Reports, 1990; 9: 14-16.

6. Lentini Z., Reyes P., Martinez C.P. et al. Androgenesis of highly recalcitrant rice genotypes with maltose and silver nitrate. Plant Science, 1995; 110: 127-138.

7. Lobanova K.I., Zhosonar M.V., Ignatova S.O. Ways of different winter wheat genotypes regeneration potential realization in anther culture. The Bulletin of Vavilov Society of Geneticists and Breeders of Ukraine, 2006; 4(1): 52-57. (In Ukrainian).

8. Orshinsky B.R., McGregor L.J., Johnson G.I.E. et al. Improved embryoid induction and green shoot regeneration from wheat anthers cultured in medium with maltose. Plant Cell Reports, 1990; 9: 365-369.

9. Otani M., Shimada T. Pollen embryo formation and plant regeneration from cultured anthers of tetraploid wheat. Journal of Genetics and Breeding, 1994; 48: 103-106.

ISSN 1996-4536 (print) • ISSN 2311-0783 (on-line) • Біологічні Студії / Studia Biologica • 2015 • Том 9/№3-4 • C. 99-106 
10. Park S.G., Ubaidillah M., Kim K-M. Effect of maltose concentration on plant regeneration of anther culture with different genotypes in rice (Oryza sativa L.). American Journal of Plant Sciences, 2013; 4 (11): 2265-2270.

11. Piccirilli M., Arcioni S. Haploid plants regenerated via anther culture in wild barley (Hordeum spontaneum cv. Kock). Plant Cell Reports, 1991; 10: 273-276.

12. Roberts-Oehlschlager S.L., Dunwell J.M. Barley anther culture: Pretreatment on mannitol stimulates production of microspore-derived embryos. Plant Cell, Tissue and Organ Culture, 1990; 20: 235-240.

13. Rokytskyy P.F. Biological statistics. $3^{\text {rd }}$ ed. Minsk: Visshaya Shkola, 1973: 320 p. (In Russian).

14. Strickland S.D., Nichol J.W., McCall C.M. et al. Effect of carbohydrate source on alfalfa somatic embryogenesis. Plant Science, 1987; 48(2): 113-121.

15. Slama Ayed O., De Buyser J., Picard E. et al. Effect of pre-treatment on isolated microspores culture ability in durum wheat (Triticum turgidum subsp. durum Desf.). Journal of Plant Breeding and Crop Science, 2010; 2(2): 30-38.

16. Tiwari S. Anther culture and long-term culture ability of androgenic calli in durum wheat (Triticum durum Desf.). Wheat Information Service, 2003; 96: 15-19.

17. Trottier M.C., Collin J., Comeau A. Comparison of media further aptitude in wheat anther culture. Plant Cell, Tissue and Organ Culture, 1993; 35: 59-67.

18. Zambriborsh I.S., Dobrova H.O., Shestopal O.L. et al. Induction of new formation in in vitro anther culture triticum dicoccum (schrank) schuebl. Bulletin of Scientific Works Sworld, 2013; 50: 28-32.

19. Zapata F.J., Aldemita R.R., Ella E.S. et al. Isolated microspore culture of rice at the international rice research institute. Proceedings of the Second International Rice Research Genetics Symposium 14-18 May 1990, Manila, 1990. P. 311-319.

ISSN 1996-4536 (print) • ISSN 2311-0783 (on-line) • Біологічні Студії / Studia Biologica • 2015 • Том 9/№3-4 • С. 99-106 


\title{
ВПЛИВ ВМІСТУ ДЖЕРЕЛА ВУГЛЕЦЮ В ІНДУКЦІЙНОМУ ПОЖИВНОМУ СЕРЕДОВИЩІ НА ЕФЕКТИВНІСТЬ КАЛЮСОУТВОРЕННЯ I РЕГЕНЕРАЦІЇ РОСЛИН У КУЛЬТУРІ ПИЛЯКІВ ПШЕНИЦІ ТВЕРДОÏ IN VITRO
}

\author{
Г. О. Доброва, І. С. Замбріборщ, О. Л. Шестопал \\ Селекційно-генетичний інститут - \\ Національний центр насіннєзнавства та сортовивчення \\ Овідіопольська дорога, 3, Одеса 65036, Україна \\ e-mail: dobrovaann@gmail.com
}

Подвоєні гаплоїди є важливими для селекції твердої пшениці. Одним із найбільш поширених методів їх отримання $є$ метод культури пиляків. Ефективність цього методу залежить від різних фракторів, таких як умови культивування і генотип рослин. Важливим $€$ дослідження впливу умов культивування на індукцію новоутворень і регенерацію рослин. Вміст джерела вуглецю у поживному середовищі впливає на процес андрогенезу in vitro. Вивчили спроможність до андрогенезу in vitro чотирьох озимих і чотирьох ярих гібридів F2 пшениці твердої. Порівнювали два індукційних поживних середовища з різними джерелами вуглецю. Середовище C17М містило мальтозу в концентрації 90 г/л. Середовище С17н містило цукрозу в концентрації 60 г/л і глюкозу в концентрації 17,5 г/л. Було встановлено, що рівень індукції новоутворень і регенерації альбіно рослин був вищим на середовищі з мальтозою для всіх протестованих генотипів. Рівень регенерації зелених рослин був низьким. Отримали зелені регенеранти лише трьох генотипів. Три подвоєні гаплоїди генотипу T12, що регенерували з новоутворень, отриманих на середовищі С $17 \mathrm{M}$, були успішно адаптовані до умов ґрунту і вирощувались у ростовій камері до отримання насіння. Для статистичного аналізу використовували двофакторний дисперсійний аналіз. Було розраховано ступінь впливу кожного фактора. Встановили, що генотип рослин мав найбільший вплив на індукцію новоутворень. Взаємодія факторів генотипу й індукційного поживного середовища найсильніше впливала на регенерацію альбіно і зелених рослин.

Ключові слова: тверда пшениця, подвоєні гаплоїди, культура пиляків, мальтоза.

\section{ВЛИЯНИЕ ИСТОЧНИКА УГЛЕРОДА В СОСТАВЕ ИНДУКЦИОННОЙ ПИТАТЕЛЬНОЙ СРЕДЫ НА ЭФФЕКТИВНОСТЬ КАЛЛУСООБРАЗОВАНИЯ И РЕГЕНЕРАЦИИ РАСТЕНИЙ В КУЛЬТУРЕ ПЫЛЬНИКОВ ПШЕНИЦЫ ТВЕРДОЙ IN VITRO}

\section{А. А. Доброва, И. С. Замбриборщ, О. Л. Шестопал \\ Селекционно-генетический институт - Национальный центр семеноводства и сортоизучения Овидиопольская дорога, 3, Одесса 65036, Украина e-mail: dobrovaann@gmail.com}

Получение удвоенных гаплоидов важно для селекции твердой пшеницы. Одним из самых распространенных методов получения удвоенных гаплоидов

ISSN 1996-4536 (print) • ISSN 2311-0783 (on-line) • Біологічні Студії / Studia Biologica • 2015 • Том 9/№3-4 • С. 99-106 
считается метод культуры пыльников. Эффективность этого метода зависит от разных факторов, таких как условия культивирования и генотип растений. Важно исследовать влияние условий культивирования на индукцию новообразований и регенерацию растений. Источник углевода в питательной среде влияет на процесс андрогенеза in vitro. Изучили способность к андрогенезу in vitro четырех озимых и четырех яровых гибридов F2 пшеницы твердой. Сравнивали две индукционные питательные среды с разными источниками углевода. Среда С17M содержала мальтозу в концентрации 90 г/л. Среда С17н содержала сахарозу в концентрации 60 г/л и глюкозу в концентрации 17,5 г/л. Установили, что уровень индукции новообразований и регенерации альбино растений был выше на среде с мальтозой для всех протестированных генотипов. Уровень регенерации зеленых растений был низким. Получили зеленые регенеранты только трех генотипов. Три удвоенных гаплоида генотипа T12, которые регенерировали из новообразований, полученных на среде C17M, были успешно адаптированы в почве и выращивались в ростовой камере до получения семян. Для статистического анализа использовали двухфакторный дисперсионный анализ. Рассчитали степень влияния каждого фактора. Установили, что генотип растений влиял на индукцию новообразований в наибольшей степени. Взаимодействие факторов генотипа и индукционной питательной среды имело наибольшее влияние на регенерацию альбино и зеленых растений.

Ключевые слова: твердая пшеница, удвоенные гаплоиды, культура пыльников, мальтоза.

Одержано: 10.11 .2015

ISSN 1996-4536 (print) •ISSN 2311-0783 (on-line) • Біологічні Студії / Studia Biologica • 2015 • Том 9/№3-4 • С. 99-106 